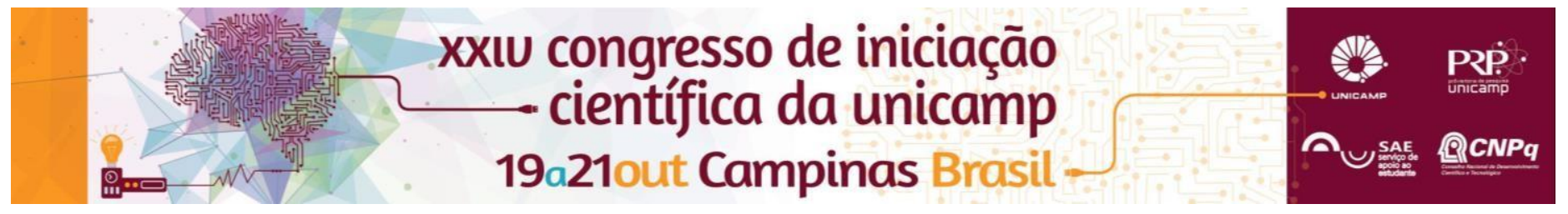

\title{
Exercícios do olhar: um incurso na prosa ensaística de Gilda de Mello e Souza.
}

\author{
Autoras: Bárbara Luisa Fernandes Pires*, Mariana Miggiolaro Chaguri.
}

\section{Resumo}

O presente trabalho objetivou apresentar alguns aspectos da produção ensaística de Gilda de Mello e Souza (19192005). Ao traçar um esboço da trajetória intelectual da autora, que estruturada no ensaísmo crítico, estabeleceu um método de escrita livre e original no campo das artes, da estética e do pensamento brasileiro, buscou-se compreender a operação que a autora executa ao tratar das relações entre arte e sociedade, forma estética e forma social nuançados no entremeio do contexto de composição do conhecimento da tradição europeia e da brasileira.

\section{Palavras-chave:}

Gilda de Mello e Souza, arte e sociedade, ensaísmo brasileiro.

\section{Introdução}

Gilda de Mello e Souza reconhecida como grande expressão da intelectualidade brasileira, marca sua trajetória no ensaísmo através de um ponto de vista crítico. Percorreu diversas áreas nos campos da estética e da sociologia, dedicando-se ao longo de sua trajetória intelectual ao estudo das formas e da sociedade brasileira. Publicou livros e ensaios sobre moda, literatura, artes plásticas, cinema, música, dança e teatro. Ingressou no ano de 1937 em uma das primeiras turmas da recém fundada Faculdade de Filosofia Ciências e Letras - FFCL onde se formou em 1939. De família radicada em Araraquara no interior paulista, desloca-se aos doze anos para a cidade de São Paulo onde passa a viver na companhia do primo e escritor Mário de Andrade. Uma das primeiras mulheres a estudar na faculdade foi aluna e discipula dos professores da "missão francesa": Roger Bastide, Jean Maugüé e Claude Lévi-Strauss. Gilda participou da fundação da revista Clima, em 1941, junto com outros colegas da faculdade, publicando artigos e contos.

Acreditamos que o contexto no qual a autora esta inserida possa ser compreendido como um indício para a construção de seu olhar de intérprete. Em segundo momento da pesquisa, ao articularmos a experiência social e a organização formal, passamos ao estudo e contato direto com as obras e ensaios da autora. ${ }^{1}$ Sugerimos como hipótese, que sua obra operacionaliza uma conexão entre a análise estética e a análise sociológica. Ao assumirmos a hipótese de que ambas as análises são constituintes de sua metodologia crítica, procuramos compreender como foi possível aclimatar, reposicionar e dialogar criativamente com tradições estéticas europeias e brasileiras através da análise dos temas e problemas que Gilda de Mello e Souza toma como objeto em suas obras, criando assim, uma análise ensaísta particular da cultura e da sociedade brasileira.

\section{Resultados e Discussão}

Á vista da obra de Gilda de Mello e Souza, se tentarmos definir qual é o seu tipo de análise, sobressai a perspicácia sociológica do olhar diante das formas estéticas e dos gestos. Suas análises, sob influências teóricas europeias e brasileiras e, muitas vezes guiadas pela descoberta indiciária do "pormenor significativo", recuperaram o sentido da formação da sociedade brasileira, seja por exemplo, através da moda ou da pintura. O traço sensível da escrita da autora nos leva ao encontro das figurações simbólicas e das práticas sociais, como fontes interpretativas da cultura brasileira e do entendimento desta. Os ensaios e livros deixados por ela revelam um percurso que evidencia uma concepção de crítica aberta e dinâmica e, sobretudo, interdisciplinar. Gilda de Mello e Souza, nos ensina a olhar, criando mediações a partir da relação entre a arte e a sociedade, a autora compõe seu argumento estético como fonte interpretativa das formas complexas da vida social e de seu processo constituinte.

\section{Conclusões}

A paixão pela análise das formas e pela experiência dos gestos são configuradas na obra de Gilda como guias e condutores da interpretação de variados aspectos do sistema cultural brasileiro. Ao dialogar com diferentes tradições estéticas no contexto nacional, a autora estabelece um jogo de mediações e de desmembramento dos objetos que analisa. Na mediação que realiza entre a forma artística e a forma social, Gilda de Mello e Souza configura um tipo de análise particular de interpretação do Brasil que, ao perpassar as mais variadas formas de arte e os vários momentos da sociedade brasileira, acaba por realizar um ensaísmo crítico das formas através de um exercício minucioso de orientação do olhar, um olhar de "perito".

\section{Agradecimentos}

À Profa. Dra. Mariana Miggiolaro Chaguri pela estimulante e dedicada orientação. Ao CNPq pelo apoio institucional e pela possibilidade de pesquisa. Aos professores, familiares e amigos que incentivaram e contribuíram de forma direta ou indireta para a realização dessa pesquisa.

\footnotetext{
Mello e Souza, G. . O espírito das roupas: a moda no século XIX. São Paulo: Companhia das Letras, 1987. O tupi e o Alaude, São Paulo: Editora 34, 2003 A ideia e o figurado. São Paulo: Editora 34, 2005. . Exercícios de leitura. 3.ed. São Paulo: Companhia das Letras, [1980]
} 